\title{
DOCTRINAL INNOVATION IN INTERNATIONAL CRIMINAL LAW: HARMS, VICTIMS, AND THE EVOLUTION OF THE LAW
}

\author{
PATRICK J. KEENAN*
}

\begin{abstract}
There seems to be no limit to the kinds of atrocities that are committed during armed conflicts. During World War II, the Nazi regime committed unprecedented horrors that no legal system had foreseen. During the wars in Sierra Leone in the 1990s, combatants engaged in forms of cruelty that the law had not anticipated. Even now, in the conflict in Syria, combatants are using novel weapons to inflict harms for which the law cannot fully account. When faced with novel harms, how should prosecutors respond? They cannot simply create from whole cloth a brand-new crime; doing so would violate the defendant's rights. And they cannot simply ignore the conduct if they are to do their jobs effectively and deliver justice to victims and perpetrators.

This Article shows how prosecutors can accomplish these seemingly contradictory goals. I argue that when faced with novel conduct, prosecutors should rely on a three-step process. First, they must identify with some precision the harms associated with the allegedly criminal conduct. Second, they must show that these harms are similar in type and magnitude to harms associated with established crimes. Third, they must show that the new crime is

* Professor at the University of Illinois College of Law. I am grateful to Andy Leipold and Verity Winship for helpful comments and conversations. Barbara Hola provided generous comments and suggestions. I am also grateful to all the participants in the 2019 International Criminal Court Scholars Forum, particularly Rogier Bartels, J.D. Bowers, Nancy Amoury Combs, Yvonne Dutton, Emma Irving, Dov Jacobs, Matthew Kane, Ciara Laverty, Linda Malone, Joseph Powderly, Leila Nadya Sadat, Carsten Stahn, Milena Sterio, Jennifer Trahan, Hannibal Travis, Larissa van den Herik, and Elies van Sliedregt. Any remaining errors are my own.
\end{abstract}


different enough from the established crime to justify using the novel crime.

Using a harms-based approach will allow prosecutors to address novel harmful conduct more effectively and will help to ensure that harms that have been ignored for too long will be treated more appropriately. For much of the history of armed conflicts, harms inflicted on women and girls were either ignored or woefully inadequately addressed. A harms-based approach can begin to close this accountability gap by ensuring that wrongful conduct, regardless of the status of the victim, is fully addressed. 


\section{TABLE OF CONTENTS}

I. The Problem of Innovation in International Criminal

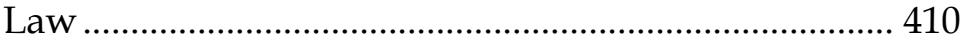

II. A Harms-Based Approach ............................................. 415

a. The Doctrinal Roots of a Harms-Based Approach ...... 418

b. A Harms-Based Approach is Consistent with the History and Structure of the Law ............................................ 423

c. Limitations ............................................................ 428

i. Subjectivity ................................................. 428

ii. $\quad$ Systemic Causes and Effects ........................... 429

iii. $\quad$ The Legality Principle ....................................... 429

iv. The Politics of Criminalization ........................ 432

III. Extensions and Complications ...................................... 435

a. Community-Based Harms ........................................ 435

b. Harms to Non-Human Species and the Environment 442

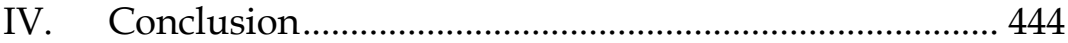




\section{THE PROBLEM OF INNOVATION IN INTERNATIONAL CRIMINAL LAW}

An intractable problem in international criminal law is how to define novel crimes. ${ }^{1}$ Human cruelty seemingly has no end. Every conflict brings new conduct that victims, advocates, and scholars believe must be punished using criminal law. ${ }^{2}$ For prosecutors, this creates a common but difficult challenge: how to use existing law to address novel or unusual conduct. International criminal law cannot stand still. It must evolve to fulfill the expectations of its proponents: ending impunity, providing recourse and justice for victims, and contributing to transitional justice. ${ }^{3}$ What makes this particularly challenging is the legality principle. The legality

1 Many of these innovations have been in the characterization of novel conduct, which is the principal focus of my analysis. See Janet Halley, Rape at Rome: Feminist Interventions in the Criminalization of Sex-Related Violence in Positive International Criminal Law, 30 MiCH. J. INT'L L. 1, 49-70 (2008) (arguing that crimes against women and girls should be treated with different international criminal law and showing how a feminist jurisprudence could facilitate that goal); Darryl Robinson, The Identity Crisis of International Criminal Law, 21 LEIDEN J. INT'L L. 925, 933-46 (2008) (arguing that judicial interpretation of contested provisions of international criminal law has produced innovations that are contrary to norms of due process); Sylvain Vité, Between Consolidation and Innovation: The International Criminal Court's Trial Chamber Judgment in the Lubanga Case, in 15 YEARBOOK OF INTERNATIONAL HUMANITARIAN LAW 2012, 61, $70-76$ (Terry D. Gill et al. eds., T.M.C. Asser Press 2014) (analyzing decision of the International Criminal Court that addressed innovative means of criminalizing the use child soldiers in armed conflicts). Other innovations have come with respect to forms of criminal liability. For a thorough exploration of the development of alternative forms of liability, see generally Allison Marston Danner \& Jenny S. Martinez, Guilty Associations: Joint Criminal Enterprise, Command Responsibility, and the Development of International Criminal Law, 93 CAL. L. REV. 77 (2005) (critically analyzing the development of various forms of vicarious liability in international criminal law).

2 See, e.g., W.H. Lawrence, Nazi Death Camp a Scene of Horror, N.Y. TIMES, Oct. 6, 1944 (describing discovery and details of concentration camp in Estonia); The Nuremberg Judgment, reprinted in 2 THE LAW OF WAR: A DOCUMENTARY HISTORY, 922, 949-51 (Leon Friedman ed., 1972) (describing novel Nazi practice of using concentration camps to terrorize the civilian population); Norimitsu Onishi, Sierra Leone Measures Terror in Severed Limbs, N.Y. TIMES, Aug. 22, 1999, at A3 (describing new phenomenon of combatants hacking off the hands of civilians during the armed conflict in Sierra Leone); Max Fisher, What Makes Syria's 'Barrel Bombs' So Scary, WASH. POST (Dec. 24, 2013, 1:31 PM), https://www.washingtonpost.com/news/worldviews/wp/2013/12/24/what-m akes-syrias-barrel-bombs-so-scary/ [https://perma.cc/UMB4-24S7] (describing barrel bombs as "latest tool of terror" in the war in Syria).

3 For a thorough discussion of the various objectives of international criminal law, see generally Patrick J. Keenan, The Problem of Purpose in International Criminal Law, 37 Mich. J. INT'L L. 421 (2016). 
principle requires, in part, "that conduct must be criminalized and penalties fixed in advance of any criminal prosecution." 4 A strict interpretation of this principle would mean that those seeking to prosecute a defendant for novel criminal conduct must use an existing charge even if the existing crime does not adequately describe the harmful conduct. ${ }^{5}$ International criminal tribunals thus face a dilemma: how to account for novel conduct while respecting one of the foundational principles of international criminal law. Put slightly differently, how should doctrinal innovation take place in international criminal law?

Because international criminal law is a developing field, the process of defining crimes is different than in domestic courts. ${ }^{6}$ In international criminal tribunals, judges determine, after the allegedly criminal conduct has occurred, whether prosecution ${ }^{7}$ and punishment is consistent with the law. ${ }^{8}$ In the main, it is in this way that international criminal law evolves. Contrast this with domestic criminal law, in which the law evolves both through legislative processes and judicial rulings. ${ }^{9}$ Significant innovations in international criminal law are often met with a similar criticism: that the new crime for which a morally blameworthy defendant was being held accountable was not defined as a crime at the time the

4 Beth Van Schaack, Crimen Sine Lege: Judicial Lawmaking at the Intersection of Law and Morals, 97 GEO. L.J. 119, 121 (2008).

5 For a thorough history of the ways that international criminal tribunals have treated the legality principle in their rulings, see generally $i d$. at 125-41.

6 For just a small sample of the ways in which international criminal law is still evolving, see generally Theodor Meron, Procedural Evolution in the ICTY, $2 \mathrm{~J}$. INT'L CRIM. JUST. 520 (2004) (analyzing evolutions in international criminal procedure); Phillip Weiner, The Evolving Jurisprudence of the Crime of Rape in International Criminal Law, 54 B.C. L. REV. 1207 (2013) (examining the ways that international criminal tribunals have begun to prosecute rape committed during times of armed conflict); Nancy Amoury Combs, Grave Crimes and Weak Evidence: A Fact-Finding Evolution in International Criminal Law, 58 HARV. INT'L L.J. 47 (2017) (arguing that international criminal institutions have evolved rules for assessing evidence that are not always consistent with the written rules of procedure).

7 Van Schaack, supra note 4, at 140.

8 For example, Beth Van Schaack has argued that international criminal law differs from domestic criminal law because there is no "standing world legislature that can fill interstices and lacuna, modernize ancient prohibitions, or fix faulty formulations." Id. at 137.

9 For a discussion of the complex social and legal forces that contribute to the evolution of domestic criminal law, see generally Kay L. Levine, The External Evolution of Criminal Law, 45 AM. CRIM. L. REV. 1039 (2008). See also Ben Rosenberg, The Growth of Federal Criminal Common Law, 29 AM. J. CRIM. L. 193, 210-14 (2002) (describing the ways that federal criminal law evolves, which implicate both statutes and judicial decisions). 
acts were committed. ${ }^{10}$ Proponents of prosecution typically rely on arguments that any defendants who committed terrible acts are unlikely to be held accountable elsewhere and must have known that their conduct was criminal. ${ }^{11}$ Those arguing for strict enforcement of the principle of nullum crimen sine lege have the unenviable task of arguing that admittedly harmful acts are not being characterized appropriately under the law. To many scholars and advocates, the application of the legality principle appears decidedly unprincipled. ${ }^{12}$ Prosecutors have succeeded in creating

10 See, e.g., Prosecutor v. Brima, Case No. SCSL-2004-16-A, Judgment, ๆ $197-$ 198 (Feb. 22, 2008) (addressing parties' arguments regarding the application of the legality principle to the novel crime of forced marriage). For a scholarly examination of such claims, see generally Jordan J. Paust, Nullum Crimen and Related Claims, 25 DENV. J. INT'L L. \& POL'Y 321 (1997).

11 The argument against creating new laws or tribunals is not new. See, e.g., Charles E. Wyzanski, Nuremberg: A Fair Trial? A Dangerous Precedent, ATLANTIC (April 1946), https://www.theatlantic.com/magazine/archive/1946/04/nuremberg-a-fair-tria 1-a-dangerous-precedent/306492/ [https://perma.cc/G5XT-MQ8V] (arguing that the conduct of the Nazis was abhorrent, but that the new charges and the new tribunal were not consistent with existing law). For a thorough weighing of the issues in a contemporary context, see Prosecutor v. Norman, Case No. SCSL-200414-AR72(E), Decision on Preliminary Motion Based on Lack of Jurisdiction (Child Recruitment) (May 31, 2004). There, the defense objected to charges of recruiting child soldiers. Id. I 1 . The majority of the court held that the novel charge was permissible because the elements of the offense were contrary to international humanitarian law and subject to prosecution in the domestic legal systems of many states. Id. I 50-51, 54. Noteworthy for my purposes is the dissent. Justice Robertson wrote that the legality principle can be "highly inconvenient - especially in relation to conduct which is abhorrent or grotesque." Prosecutor v. Norman, Case No. SCSL-2004-14-AR72(E), Decision on Preliminary Motion Based on Lack of Jurisdiction (Child Recruitment), Dissenting Opinion of Justice Robertson $\mid 12$ (May 31, 2004). Justice Robertson acknowledged that the conduct was harmful but argued that it was not illegal at the time it was committed. Id. $\mid 13$. He argued that in most legal systems it is possible to determine a date certain on which particular conduct becomes illegal. Id. \12. But in the international context, such a specific date is often difficult to discern. Id. In the face of this, he cautioned that "international law judges" must resist the temptation to circumvent the legality principle to permit the prosecution of conduct "which they regard as seriously antisocial or immoral." Id.

12 See, e.g., Van Schaack, supra note 4, at 133-72 (analyzing in detail the various ways that international criminal tribunals have eroded the legality principle). Van Schaack concludes that although the legality defense

is a frequent defense in ICL in the face of novel substantive charges and forms of responsibility or expansive interpretations of established doctrines.... [International criminal] tribunals have allowed defendants to be prosecuted for offenses, or under forms of responsibility, that were not part of positive law at the time the defendants acted.

Id. at 172 . 
new crimes and theories of liability and in expanding the boundaries of existing crimes. ${ }^{13}$

In this Article, I argue that international criminal tribunals can rely on an analysis of the type and magnitude of harm caused by the underlying conduct to determine whether novel conduct may be subject to prosecution. In the past, tribunals have conducted this analysis to determine whether the underlying novel conduct is sufficiently similar to conduct already subject to prosecution to satisfy the legality principle. To be sure, tribunals still engage in some of the traditional legality analysis by considering the elements of the novel offense, how well they map onto existing crimes, and other factors. ${ }^{14}$ But increasingly, the approach that has the most to commend is the harms analysis.

This Article proceeds as follows. In Section II, I discuss what exactly constitutes a harms-based approach. I argue that under such an approach, prosecutors would be required to define precisely the harms caused by the novel conduct, demonstrate that those harms are similar to those caused by established crimes, and show that the new crime is not identical to existing crimes. In this Section, I also show that a harms-based approach is consistent with the existing law and should be satisfactory to some of the leading theories of international criminal law. In Section III, I show how a harms-based approach might work in cases. I argue that this approach would allow prosecutors to address community-based harms through the law of pillage and address environmental harms.

Before moving on, a short clarification is in order. I do not argue that equivalence of harms should be the only criterion by which to determine if an act should be subject to international criminal prosecution. Recognizing a wider range of harms is important for the law to fulfill its potential, but equally important is attention to basic due process norms that a fair criminal procedure would

13 See, e.g., Susana SáCouto, Leila Nadya Sadat \& Patricia Viseur Sellers, Collective Criminality and Sexual Violence: Fixing a Failed Approach, 33 LEIDEN J. INT'L L. 207, 213-18 (2020) (describing an increase in prosecution of rape and sexual assault in the ad hoc tribunals and analyzing the various reasons for the increase); see also Danner \& Martinez, supra note 1, at 103-31 (describing the development of new modes of liability that had the effect of expanding liability and easing the burden on prosecutors).

14 See generally Van Schaack, supra note 4, at 133-72 (analyzing the process by which international criminal tribunals evaluate legality defense claims). 
demand. ${ }^{15}$ M. Cherif Bassiouni, arguing that international criminal law should be attentive to criminal law issues, provided a useful framework of the necessary characteristics of an international crime. ${ }^{16}$ Bassiouni argued that, among other things, international crimes must be specified in an international convention or under customary international law with sufficient particularity to allow the defendant to respond to the charges. ${ }^{17}$ My approach is not an argument in favor of returning to "rudimentary" processes applied at the Nuremberg and Tokyo tribunals. ${ }^{18}$ Instead, I argue that there is increased space in the law to attend to harms that have not been fully considered thus far.

Despite this caveat, there are important policy reasons that support a harms-based analysis. International criminal law continues to evolve in significant ways and some of the most consequential changes have occurred in novel ways that have not yet been fully explored. As international criminal law moves away from a rigid, category-based approach to defining crimes towards a harms-based approach, there is space for international criminal law to address more unwanted conduct and come closer to fulfilling its potential. In an attempt to ensure that the cases they prosecute account for as many harms as possible, prosecutors have created new substantive crimes and found ways to accommodate these new crimes into the broad existing categories of crimes against humanity

15 There is a small but growing literature on the procedures followed in international criminal tribunals. NANCY AMOURY COMBS, FACT-FINDING WITHOUT FACTS: THE UNCERTAIN EVIDENTIARY FOUNDATIONS OF INTERNATIONAL CRIMINAL CONVICTIONS (2010), meticulously documented the ways that many international criminal tribunals have based their decisions on shaky evidence. See also Kai Ambos, International Criminal Procedure: "Adversarial", "Inquisitorial" or Mixed?, 3 INT'L CRIM. L. REV. 1, 5-7 (2003) (describing the sometimes confused procedural issues that affect cases in international criminal tribunals); Gregory S. Gordon, Toward an International Criminal Procedure: Due Process Aspirations and Limitations, 45 COLUM. J. TRANSNAT'L L. 635, 641-70 (2007) (analyzing the criminal procedural characteristics and deficits of international criminal tribunals from Nuremberg through the international criminal court). See generally Diane Marie Amann, Harmonic Convergence? Constitutional Criminal Procedure in an International Context, 75 IND. L.J. 809 (2000) (analyzing the means by which domestic criminal procedure rules and norms become integrated into international criminal tribunals).

16 M. Cherif Bassiouni, The Penal Characteristics of Conventional International Criminal Law, 15 CASE W. RES. J. INT'L L. 27, 28 (1983).

17 Id.

18 See generally Theodor Meron, Reflections on the Prosecution of War Crimes by International Tribunals, 100 AM. J. INT'L L. 551, 569-71 (2006) (describing the rudimentary provisions on criminal procedure in the London and Tokyo Charters). 
or genocide. ${ }^{19}$ I show how the harms-based approach has been used to expand the bounds of international criminal law by defining new crimes or new modes of commission for existing crimes. This has happened largely in an organic, ground-up manner: prosecutors listen to victims and their advocates to understand the true harms caused by the perpetrators, then craft charges to fit these harms. This change is noteworthy for several reasons. First, it shows how victims can exert power in a juridical institution to nudge the law forward even when states or others push back. Second, it shows that conventional accounts of how the law changes - which focus almost exclusively on states - can miss important changes happening at the ground level. Finally, it shows how international law can take account of harms to vulnerable victims when other avenues are closed to those actors. For example, some scholars and advocates have long pushed for international criminal law to address harms done to the environment or to non-human species. ${ }^{20}$ If the conception of harm is broadened, there might well be space in the law to address climate crimes. Similarly, this approach might simplify attempts to arrive at a definition of terrorism.

\section{A HARMS-BASED APPROACH}

On July 13, 2005, a young woman testified before the Special Court of Sierra Leone about the abuse she suffered during the wars in West Africa. ${ }^{21}$ Known in the transcript only as Witness TF1-094, she told the court about the day the fighters from the Sierra Leone Army - one of the many warring factions in the complex conflictcame to her village. ${ }^{22}$ The fighters rounded up civilians and separated them into groups. ${ }^{23}$ They killed her parents and many

19 See discussion infra Part II.

20 For a discussion on international criminal law and harm to non-human species, see Lynn Berat, Defending the Right to a Healthy Environment: Toward a Crime of Geocide in International Law, 11 B.U. INT'L. L.J. 327, 340-48 (1993).

21 Trial Transcript at 24-57, Prosecutor v. Brima, Case No. SCSL-2004-16-T (July 13, 2005), http://www.rscsl.org/Documents/Transcripts/AFRC/AFRC071305.pdf [https:/ / perma.cc/9CZ8-RTCX].

22 Id.

23 Id. at 27. The Special Court for Sierra Leone was created as a joint endeavor involving the United Nations and the government of Sierra Leone "to prosecute persons who bear the greatest responsibility" for the violence in Sierra Leone in the late 1990s. Agreement Between the United Nations and the Government of Sierra 
others in the village.24 She was captured along with other civilians and claimed by one of the fighters, whom she identified only as Andrew. ${ }^{25} \mathrm{He}$ and the other fighters took their captives to another village, where Andrew raped Witness TF1-094 for the first of many times. ${ }^{26}$ She testified that she had not yet had her first period when she was raped for the first time. ${ }^{27}$ Andrew kept her with him and continued to abuse her. Within a month of her captivity, she was pregnant. 28

Andrew considered Witness TF1-094 to be his "wife," 29 and required her to cook, clean, and do his laundry, among many other chores. 30 If she refused him, he would have killed her. 31 Throughout her pregnancy, she was forced to move from village to village to support Andrew and his fellow fighters. ${ }^{32}$ She was beaten with a stick for walking too slowly when she was six months pregnant. ${ }^{33}$ When she was seven months pregnant, Andrew was killed in a battle. ${ }^{34}$ Her baby was stillborn two months later. ${ }^{35}$

What happened to Witness TF1-094 was tragically common in the war in Sierra Leone. ${ }^{36}$ Prosecutors presented the testimony of an

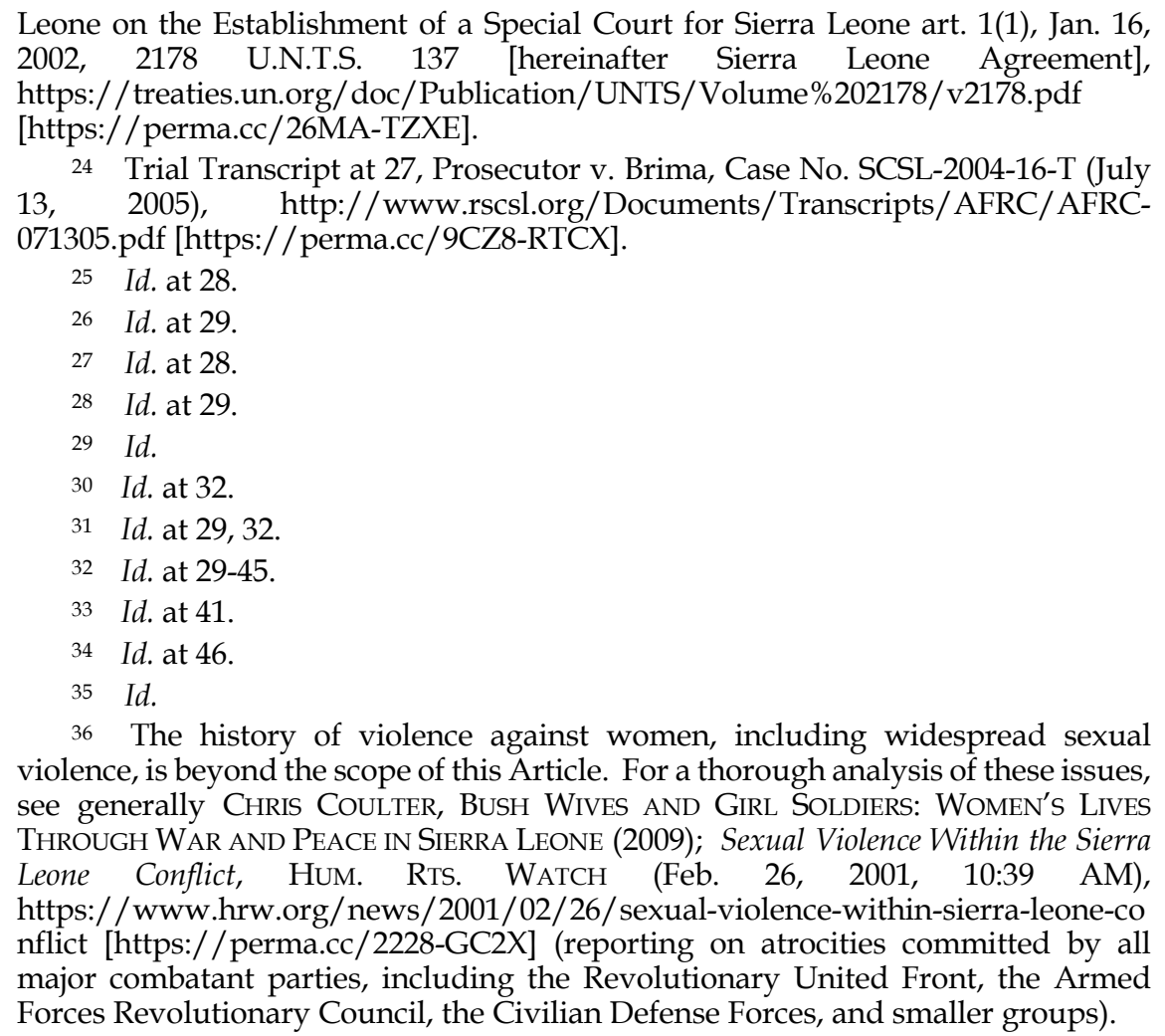


expert witness who described what she called "bush wives." 37 These were young women, like Witness TF1-094, who were subjected to both gruesome sexual violence and forced to act as a "wife" to their captors and abusers. 38

What is noteworthy about this case, and a handful of others, is that they show how prosecutors might use space in the law to address harms that are not currently fully addressed by other crimes. Before moving on, it is important to state clearly what I mean by a harms-based approach. To convince a court that novel wrongdoing should be treated as a new crime, prosecutors attempt to prove that the harms associated with the proposed new crime are of a similar type and magnitude as harms associated with an existing, established crime. ${ }^{39}$ To accomplish this, prosecutors might argue that the harms involved the same or similar rights - like the right to bodily integrity, for example-and that their violation is as costly to victims as the harms associated with established crimes. This part of the analysis turns on convincing the court that the harms are similar to each other.

But even as they attempt to show that the harms are sufficiently similar as to satisfy the legality principle, prosecutors must also show that the proposed crime is different from existing crimes. ${ }^{40}$

37 Prosecutor v. Brima, Case No. SCSL-04-16-T, Judgment, ๆ 233, 88 n.419 (June 20, 2007).

$38 \quad$ Id. $ๆ 991$.

39 This part of the analysis is similar to the consideration of the gravity of an offense that international criminal tribunals conduct in many cases. In cases alleging that the defendant's conduct amounted to the crime against humanity of other inhumane acts, prosecutors must show that the defendant's actions "are sufficiently similar in gravity to" other acts listed in the crimes against humanity statute. Prosecutor v. Brima, Case No. SCSL-2004-16-A, Judgment, II 198 (Feb. 22, 2008). In addition to its doctrinal importance, an analysis of the gravity of an offense is "the primary conceptual foundation of international law's authority to administer criminal justice." Margaret M. deGuzman, How Serious are International Crimes? The Gravity Problem in International Criminal Law, 51 COLUM. J. TRANSNAT'L L. 18, 20 (2012). Indeed, the International Criminal Court must determine that a case is "of sufficient gravity" in order to find it admissible. Rome Statute of the International Criminal Court art. 17, July 17, 1998, 2187 U.N.T.S. 3 [hereinafter Rome Statute]. For a scholarly analysis of the Rome Statute's gravity requirement, see generally Susana SáCouto \& Katherine Cleary, The Gravity Threshold of the International Criminal Court, 23 AM. U. INT'L L. REV. 807 (2008).

40 See Prosecutor v. Delalic, Case No. IT-96-21-A, Judgment, q 412 (Int'1 Crim. Trib. for the Former Yugoslavia Feb. 20, 2001). There the court held that "multiple criminal convictions entered under different statutory provisions but based on the same conduct are permissible only if each statutory provision involved has a materially distinct element not contained in the other. An element is materially 
They must justify the choice to use a novel crime instead of relying on an established crime. This is done using a version of the sameelements test, which requires prosecutors to show that each crime contains an element not contained in the other. ${ }^{41}$ Some overlap of elements is permissible, but complete overlap is not. Similarly, one crime may not be subsumed within another. ${ }^{42}$

In the end, I argue that the harms-based approach requires prosecutors to do three things. First, they must identify with some precision the harms associated with the allegedly criminal conduct. Second, they must show that these harms are similar in type and magnitude to harms associated with established crimes. Third, they must show that the new crime is different enough from the established crime to justify using the novel crime.

\section{a. The Doctrinal Roots of a Harms-Based Approach}

The law has always struggled to keep up with events. Legal institutions - both juridical entities and the rules they apply-are inherently conservative; they move slowly, relying on precedent, and change incrementally. International criminal law, and other areas of international law such as humanitarian law and human rights law, have had to change quickly in response to atrocities. Genocide was recognized as a crime because of the horrors of the Holocaust. 43 The conceptual foundations for the criminalization of the underlying actions had been constructed long before, to be

distinct from another if it requires proof of a fact not required by the other." $I d$. In a later case, Prosecutor v. Kunarac, Case No. IT-96-23 \& IT-96-23/1-A, Judgment, 1 168, 51 n.226 (Int'1 Crim. Trib. for the Former Yugoslavia June 12, 2002), the ICTY wrote that the test articulated in Delalic came from Blockburger v. United States, 284 U.S. 299, 304 (1932), which held that conviction for two offenses based on the same underlying conduct depended on "whether each provision requires proof of an additional fact which the other does not."

41 See Blockburger v. United States, 284 U.S. 299, 304 (1932) (requiring determination as to "whether each provision requires proof of a fact which the other does not").

42 Although a full exploration of the nuances of these issues is beyond the scope of this Article, the principle of ne bis in idem, which "protects an individual against double prosecution," CARSTEN STAHN, A CRITICAL INTRODUCTION TO INTERNATIONAL CRIMINAL LAW 247 (2019), is also implicated in the analysis. See id. at 247-50 (analyzing parameters of the ne bis in idem principle in international criminal prosecutions).

43 deGuzman, supra note 39 , at 41. 
sure, ${ }^{44}$ but it took the atrocities of the second World War to galvanize support for prosecution of the crime. ${ }^{45}$ During the genocide in Rwanda, there were hundreds of thousands of rapes committed alongside the 500,000 to 1,000,000 killings. ${ }^{46}$ The rapes were carried out, at least in part, because doing so caused specific harms that were not caused by killing or any of the other atrocities committed. For example, researchers who studied the victimized population after the genocide found that even after the violence was over, "the terrible social stigma that accompanies rape" continued to affect survivors. ${ }^{47}$ Researchers even found that rape was used because it inflicted this stigma. ${ }^{48}$ Many survivors were ostracized, treated as if they were unfit for marriage, and struggled to raise their children. ${ }^{4}$ But when prosecutors at the International Criminal Tribunal for Rwanda were putting together the cases that they would bring, they did not initially include rape among the charges. ${ }^{50}$ Rape as genocide was charged only after a witness "spontaneously" testified in court that she had been raped. ${ }^{51}$ After the witness's testimony, the

44 See Raphael Lemkin, Genocide as a Crime Under International Law, 41 AM. J. INT'L L. 145, 146 (1947) (describing his proposal, submitted in 1933, to "declare the destruction of racial, religious or social collectivities a crime under the law of nations").

45 deGuzman, supra note 39, at 19-20, 41.

46 See, e.g., Peter Landesman, A Woman's Work, N.Y. Times MAG., Sept. 15, 2002, at 82 (describing organization and execution of campaign of mass rapes during genocide).

47 See Lisa Sharlach, Rape as Genocide: Bangladesh, the Former Yugoslavia, and Rwanda, 22 New POL. SCI. 91, 99 (2000).

48 See id. at 98-99 (summarizing evidence of the incidence of rape in Rwanda and concluding that those responsible for the genocide "used rape of women, primarily Tutsi, as a political weapon").

49 See Binaifer Nowrojee, Making the Invisible War Crime Visible: Post-Conflict Justice for Sierra Leone's Rape Victims, 18 HARV. HuM. RTs. J. 85, 104 (2005) (describing the "particular stigma and shame that attaches to rape"); CHISECHE SALOME Mibenge, Sex and InTERnational Tribunals: The ERASURE OF GENDER FROM THE WAR NARRATIVE 42, 46-47 (Bert B. Lockwood, Jr. ed., 2013) (describing the personal and social stigma attached to rape).

50 See Binaifer Nowrojee, "Your Justice is Too Slow:" Will the ICTR Fail RWANDA'S RAPE VICTIMS? 8-9 (2005) (describing ICTY prosecutor's failures to develop a strategy to prosecute crimes of sexual violence and their failure to bring such charges). See also, Prosecutor v. Akayesu, Case No. ICTR-96-4-T, Judgment, I 417 (Sept. 2, 1998) (describing procedural history of amendment of the indictment after testimony about sexual violence).

51 Kelly Dawn Askin, Gender Crimes Jurisprudence in the ICTR: Positive Developments, 3 J. INT'L CRIM. JUST. 1007, 1009-10 (2005) (describing a witness who testified that she had been raped and had heard of other rapes, and prosecutor's 
prosecutors amended several indictments to include rape charges against the defendants. What these examples demonstrate is that the law has developed mechanisms by which to accommodate novel crimes into existing categories.

The most instructive recent example comes from the Brima case in the Special Court for Sierra Leone, discussed in detail above, in which prosecutors charged the leaders of one of the armed factions with the crime of forced marriage. ${ }^{52}$ During the wars in West Africa, fighters from all of the combatant groups abused and committed atrocities against women and girls. 53 Prosecutors developed significant evidence of crimes that fit into existing categories, such as rape and other sexual violence, kidnapping, and forced labor. 54 Prosecutors could have charged these crimes within existing legal categories of crimes against humanity. ${ }^{55}$ Instead, prosecutors chose to charge Brima and his co-defendants with the novel crime of "forced marriage," as a crime against humanity. ${ }^{56}$ Prosecutors did this not because they could not have proven the other crimes but because they were convinced by survivors and advocates that the harms associated with forced marriage were different from the harms associated with the other crimes. ${ }^{57}$

subsequent amendment of the indictment to include rape charge); see Prosecutor v. Akayesu, Case No. ICTR-96-4-T, Judgment, I 416 (Sept. 2, 1998) (noting that the testimony about sexual violence was unexpected).

52 See Prosecutor v. Brima, Case No. SCSL-2004-16-PT, Indictment, q 9 51-57 (May 13, 2004) (indicting defendants for the crime against humanity of "other inhumane acts," including "forced marriage").

53 See generally Louise TAYlor, Hum. RTs. WATCH, "WE'Ll KiLl YOU IF YOU Cry": SEXUAL VIOLENCE IN THE SiERRA LEONE CONFlict (2003), https://www.hrw.org/sites/default/files/reports/sierleon0103.pdf [https://perma.cc/K7KY-VA83] (describing, based on interviews with survivors and witnesses, sexual violence against women and girls in Sierra Leone during the conflict).

54 See generally Michelle Staggs Kelsall \& Shanee Stepakoff, 'When We Wanted to Talk about Rape': Silencing Sexual Violence at the Special Court for Sierra Leone, 1 INT'L $^{\prime}$ J. TRANSITIONAL Just. 355 (2007) (describing extent of sexual violence in conflict in Sierra Leone and experiences of survivors who were prepared to testify about it).

55 See Statute of the Special Court for Sierra Leone arts. 2-4, Jan. 16, 2002, 2178 U.N.T.S.

https://treaties.un.org/doc/publication/UNTS/Volume\%202178/v2178.pdf [https://perma.cc/G2B3-ZXJ8].

56 Prosecutor v. Brima, Case No. SCSL-2004-16-PT, Indictment, ๆ 1 51-57 (May 13, 2004).

57 See Micaela Frulli, Advancing Criminal Law: The Special Court for Sierra Leone Recognizes Forced Marriage as a "New" Crime Against Humanity 6 J. INT'L CRIM. JusT. $1033,1035-36$ (2008) (describing justifications for the creation of a new crime). 
To this point I have argued that within international criminal law there is doctrinal space to account for harms that are not yet fully recognized. In this Part, I show how this observation might be applied to existing or emerging crimes. I use two examples to demonstrate the point. The first is in the crime of pillage. To date, prosecutors have typically charged pillage using what I have called an episodic theory of pillage. With a more robust understanding of a harms-based approach, prosecutors could charge pillage using systematic theory that would account for many more harms and significantly more wrongful conduct. Finally, a harms-based approach might be useful to those who advocate using international criminal law to address climate change. Wrongdoing that causes harms to the environment or to non-human species can be difficult, though not impossible, to fit into existing categories.

After showing how a harms-based approach might be used, I address some possible objections or complications. First, one of the problems with traditional approaches to defining crimes is that definitional formulae that rely on notions of harm, or of offensiveness to all mankind, often omit from consideration harms that are felt mostly by women and girls. The idea that seemingly neutral principles - that some acts are so evil that they must be punished - could be distorted by social practices or cultural norms is not itself extraordinary, but its effect on international criminal law has been significant. Done clumsily, a harms-based approach might exacerbate, or at least not remediate, this problem. Second, the harms-based approach focuses on the subjective experiences of victims. This creates a risk of moving international criminal law even further away from a system of criminal law, with strict protections for the rights of defendants, and closer to a system for the vindication of the interests of victims. Third, I consider whether the only doctrinal space for new crimes, at least those defined in large part by a harms-based approach, is as the crime against humanity of "other inhumane acts." Finally, I consider how this approach might be limited. Most important as limiting principles will be the familiar requirements that criminal charges must not violate the legality principle or other principles of due process.

Although the Trial Chamber initially rejected the prosecutor's attempts to convict Brima of forced marriage, the Appeals Chamber found that forced marriage, as defined and proven by the 
prosecution, constituted a crime against humanity. ${ }^{58}$ To reach its conclusion, the Appeals Chamber carefully considered the harms associated with each of the similar crimes, which the defendants argued rendered the crime of forced marriage inappropriate. ${ }^{59}$ The Appeals Chamber found that forced marriage shared many characteristics with crimes such as sexual slavery, but that it also had distinct harms. Both involved forced sex and deprived the victim of her liberty. But forced marriage also included "a forced conjugal association" that resulted in "great suffering, or serious physical or mental injury" to the victim. ${ }^{60}$ In addition, the Appeals Chamber found that forced marriage "implies a relationship of exclusivity" between the perpetrator and his purported wife, with the "wife" risking "disciplinary consequences for a breach of this exclusive arrangement." 61

Brima is useful for another reason: how prosecutors went about making their case. When prosecutors decided to charge the crime against humanity of forced marriage, they fitted it into an existing doctrinal category. They argued, and ultimately proved, that forced marriage was sufficiently different from other crimes and that its existence was justified and supported by the evidence. They also showed that it was sufficiently different from existing crimes insofar as addressing harms that were not addressed by other crimes. No existing crime addressed the harms that stemmed from a "forced conjugal association" or having to act as the "wife" of your captor. This balance of associating a new crime with an existing category while arguing for its distinctiveness could operate as a guide for others seeking to recognize new harms and new crimes.

58 Despite finding that the charged conduct satisfied the elements of the crime against humanity of other inhumane acts, the Appeals Chamber ultimately decided not to enter convictions for the crime. See Prosecutor v. Brima, Case No. SCSL-200416-A, Judgment, ๆ 202-03 (Feb. 22, 2008). The Appeals Chamber determined that its decision to recognize that "such conduct is criminal and that it constitutes an 'Other Inhumane Act' capable of incurring individual criminal responsibility in international law" was sufficient, and that entering cumulative convictions was not warranted. Id. ๆ 202.

59 See id. $\mid$ ๆ 187-96.

60 See id. \195.

61 See id. 


\section{b. A Harms-Based Approach is Consistent with the History and Structure of the Law}

The objective of this Article is to argue that international criminal law has the doctrinal space to accommodate more harms and to show how this might operate. This is not uncontroversial. In this Part, I argue that this approach should be appealing - or at least not objectionable - to scholars and advocates with varying theoretical approaches to the law. An explicitly harms-based approach would accomplish several goals that should be of interest to scholars and advocates of various stripes.

First, expressivists should find amenable the ways this approach accounts for separate, unique harms that are not captured by other crimes with similar elements. To the extent that increasing accountability for harms is a goal of international criminal law, this approach should help do so. This should appeal to expressivists who argue that policymakers can, under appropriate conditions, deliberately harness the potential of the law to reduce undesirable behaviors and to change the attitudes that support those behaviors. ${ }^{62}$ Expressivists argue that the "law provides information; information changes beliefs; new beliefs change behavior." 63 In international criminal law this might occur through the decisions prosecutors and courts make regarding which cases to take and which to ignore. ${ }^{64} \mathrm{It}$ might take place through sentencing or reparations decisions. ${ }^{65}$ By directly accounting for harms that are not addressed elsewhere in the law, international criminal law can send more accurate and morally-defensible signals. ${ }^{66}$ It can show that all harms matter, not

62 For a thorough account of the expressive potential of the law, see generally RichaRd H. MCADAMS, THE EXPRESSIVE POWERS OF LAW: THEORIES AND LiMITS (2015) (analyzing the ways that expressivist approaches to law and law enforcement can affect behavior).

63 Id. at 136 (emphasis omitted).

64 See, e.g., Margaret M. deGuzman, Choosing to Prosecute: Expressive Selection at the International Criminal Court, 33 MiCH. J. INT'L L. 265, 268-71 (2012) (arguing that case selection can have powerful signaling effects regarding the situations and behaviors that are worthy of condemnation).

65 See, e.g., Carsten Stahn, Reparative Justice after the Lubanga Appeal Judgment, 13 J. INT'L CRIM. JUST. 801, 809-11 (2015) (arguing that reparations decisions can reveal to victims and others the relative importance of particular crimes).

66 To be sure, the expressive potential of the law is more likely to have the desired effect under particular circumstances. See MCADAMS, supra note 62, at 17679. One of these conditions is that the audience must be able to understand and 
just those affecting powerful or favored groups. It can also harness the opprobrium that comes from prosecution and demonstrate that it can be used to protect all groups and peoples, not just those with power. 67

Consider again the cases from Rwanda and Sierra Leone. Those cases made more visible the kind of harms that often affect women and girls and that have been given too little attention for too long. ${ }^{68}$ These cases were noteworthy not just because they brought the idea of harm to the foreground of the definition of crimes.69 That had happened before and had long been a part of international criminal law. ${ }^{70}$ It was also significant to recognize what kinds of harms were important, and who the most common victims of those harms have been. ${ }^{71}$ The Rwanda cases can be seen as a before and after moment in the law. Prosecutors initially brought those cases in the same way that many prosecutors had brought cases in the past: by giving

infer the meaning associated with the legal action. Id. at 179. In the context of international criminal prosecutions, this condition is likely to be met, particularly with respect to novel crimes that owe their existence to victim pressure.

67 Separate but related to this point is the way that a harms-based approach would attach the appropriate label to wrongdoing. It comports with what Darryl Robinson calls the principle of fair labeling. See Robinson, supra note 1, at 927 (arguing that the label attached to the offense should express the wrongdoing inherent in the act and signal disapproval of the harms the offense causes).

68 See, e.g., KATHY L. GACA, Girls, Women, and the Significance of Sexual Violence in Ancient Warfare, in Sexual Violence in Conflict Zones: From the ANCIENT World TO THE ERA OF HumAN Rights 73, 87 (Elizabeth D. Heineman ed., 2011) (arguing that "the violent subjugation of women and girls through sexual assault and torment has been an integral and important part of Western warfare over the two millennia from the Bronze Age to late antiquity").

69 See Tuba InAL, LoOting AND RAPE In Wartime: LAW AND Change IN INTERNATIONAL RELATIONS 59-60 (2013) (arguing that sexual violence during armed conflict was viewed as unavoidable and mostly as a harm against the community, thereby dismissing the experiences of individual women and girls who experienced such assaults).

70 See, e.g., STAHN, supra note 42 , at 85-87 (analyzing the law of pillage, which protects property during times of armed conflict). Indeed, such prohibitions have been present in legal systems since before the advent of international criminal law as a discipline. See DAVID J. BEDERMAN, INTERNATIONAL LAW IN ANTIQUiTY 242-49 (2001) (describing history of prohibitions of particular conduct in armed conflict in antiquity).

71 See Kelly D. Askin, Sexual Violence in the Decisions and Indictments of the Yugoslav and Rwandan Tribunals: Current Status, 93 AM. J. INT'L L. 97, 99 (1999) (arguing that modern international criminal tribunals have begun to "surmount[] reluctance and other obstacles to address" crimes of sexual violence "despite their sexually graphic nature and traditional insensitivities to women's rights and needs," in contrast to the "history of impunity" for such crimes in previous tribunals). 
insufficient attention to the harms that affect women and girls. According to media reports and later evidence, there was a campaign of mass rapes that affected as many as 500,000 women and girls in Rwanda during the genocide. ${ }^{72}$ But prosecutors did not initially charge rape as a mode of genocide. It was only after survivors and their advocates brought attention to the underlying harms, and to prosecutors' failure to address those harms, that the law was used. ${ }^{73}$ In Sierra Leone, there were thousands of women and girls affected by the phenomenon of forced marriage and prosecutors (again prompted by survivors and their advocates, to be sure) used the law to account for these harms. The result has been a broadening of the kinds of harms that international criminal law will consider sufficient to warrant legal recognition. ${ }^{74}$ Harms to traditionally vulnerable or politically disfavored groups - in both cases, women and girls-were enough to change prosecutorial strategy and to justify convictions for novel crimes.

Second, the approach considers and gives weight to harms not previously countenanced by international criminal law. For much of history the law did little to address the harms that are felt by women and girls during times of armed conflict or widespread unrest. ${ }^{75}$ Expanding the definition of crimes to include these harms has been a salutary development. It can also be the impetus to consider harms that are visited upon other groups or entities. For

72 For a thorough account of the many harms experienced by survivors of sexual assault in Rwanda during the genocide, see generally Binaifer Nowrojee, Shattered Lives: Sexual Violence during the Rwandan Genocide and its Aftermath, HUM. RTS. WATCH

(1996),

https://www.hrw.org/sites/default/files/reports/1996_Rwanda_\%20Shattered \%20Lives.pdf [https:// perma.cc/V8LE-JJR9] (describing, based on interviews with survivors, the consequences of sexual violence during the genocide in Rwanda).

73 See Beth Van Schaak, Obstacles on the Road to Gender Justice: The International Criminal Tribunal for Rwanda as Object Lesson, 17 AM. U. J. GENDER SOC. POL'Y \& L. 361, 369-75 (2009) (describing the ways that prosecutors amended indictments and otherwise added charges regarding sexual violence in response to supposedly unsolicited testimony of survivors).

74 For an analysis of the lingering harms associated with sexual violence in Sierra Leone, see generally Binaifer Nowrojee, Making the Invisible War Crime Visible: Post-Conflict Justice for Sierra Leone's Rape Victims, 18 HARV. Hum RTs. J. 85 (2005) (describing the harms experience by sexual violence survivors and the legal and non-legal attempts to address those harms).

75 For example, Tuba Inal, in LOOTING AND RAPE IN WARTIME: LAW AND CHANGE IN INTERNATIONAL RELATIONS, traces the long history of the prohibition of pillage-theft during wartime-that began well before modern international criminal tribunals began work. INAL, supra note 69, at 28-58. In contrast, Inal shows that prohibitions against rape or other sexual violence during wartime were much weaker and were omitted from important legal instruments. Id. at 59-91. 
example, the harms felt by communities when their natural resources are illegally stolen might help support a more aggressive approach to the crime of pillage. ${ }^{76}$ Alternatively, environmental harms that are inflicted upon non-human species would become more important and might support a stronger approach to prosecution in that area. 77 This should appeal to many constructivist scholars because it explicitly addresses harms to the community. Constructivist scholars argue that most institutions and individuals are motivated by ideas or concepts, not merely material considerations. ${ }^{78}$ These beliefs or concepts help to create interests, which can then be led to actions. ${ }^{79}$ When there are tears to the fabric of a community that must be mended to permit the community to heal, international criminal law is often posited as a partial means by which this can happen. 80 To the extent that scholars and advocates argue that international criminal law can play an important role in post-conflict reconstruction, particularly reconstruction of the community's norms and relationships, then an approach to criminalization that directly attends to harms should be welcome. 81

Third, because a harms-based approach would include harms to previously-disfavored groups or to entities like the environment, it

76 See Patrick J. Keenan, Conflict Minerals and the Law of Pillage, 14 CHI. J. INT'L L. 524, 544-47 (2014) (arguing that the law of pillage has the potential to address widespread community-level harms).

77 See generally Linda A. Malone \& Scott Pasternack, Exercising Environmental Human Rights and Remedies in the United Nations System, 27 WM. \& MARY ENVTL. L. \& POL'Y REV. 365 (2002) (analyzing the ways that claimants might seek redress for harms to the environment and describing the enforcement difficulties that might arise). See also Shirley V. Scott, Patrick J. Keenan \& Charlotte Ku, The Creation of a Climate Change Court or Tribunal, in Climate Change AND THE U.N. SECuRITy COUNCIL 66, 69-74 (Shirley V. Scott \& Charlotte Ku, eds., 2018) (arguing that international criminal law has the doctrinal space to permit prosecution of climaterelated harms, albeit with some difficulty).

78 Martha Finnemore \& Kathryn Sikkink, Taking Stock: The Constructivist Research Program in International Relations and Comparative Politics, 4 ANN. REV. POL. SCI. 2001 391, 393 (2001).

79 Id.

80 For a discussion of the ways that international criminal law can and cannot contribute to transitional justice, see generally Peter Dixon \& Chris Tenove, International Criminal Justice as a Transnational Field: Rules, Authority and Victims, 7 INT'L J. TRANSITIONAL JUST. 393 (2013).

81 See generally Ruti G. Teitel, Transitional Justice Genealogy, 16 HARV. HuM. RTs. J. 69 (2003) (analyzing the ways that various forms of juridical institutions and legal responses to atrocities and repression can contribute to social healing). 
should appeal to rational choice scholars. ${ }^{82}$ Rational choice scholars argue that individuals act so as to maximize their utility. ${ }^{83}$ At its most basic level, this means that when individuals decide whether or not to comply with the law, they make a calculation involving the likelihood that they will be caught and the consequences they will suffer if they are caught. ${ }^{84}$ For too long, this calculation was distorted because, for example, the legal consequences of committing crimes against women and girls in times of conflict were weak, and the likelihood of prosecution was small. Similarly, because harms to the environment, communities, or to non-human species were not likely to lead to prosecution and punishment, likely wrongdoers did not face the full costs of their actions.

Finally, a benefit of a harms-based approach is that it would better comport with what some scholars have called the "fair labeling principle." 85 Darryl Robinson has described this as the requirement that "the label of the offence should fairly express and signal the wrongdoing of the accused, so that the stigma of conviction corresponds to the wrongfulness of the act." 86 Although Robinson and other scholars have focused on fair labeling with respect to modes of participation in a crime-for example, accomplice liability versus commission 87 - the concept may be applied more broadly. Defining crimes at least in part by the harms experienced by victims goes a long way toward ensuring that the label attached to the crime expresses the underlying harmful conduct. To take an obvious example, in Sierra Leone it was

82 For a thorough exploration of the ways that a rational choice model can explain international law, see ANDREW T. GUZMAN, HOW INTERNATIONAL LAW WORKS: A RATIONAL CHOICE THEORY (2008).

83 See, e.g., Jack L. Goldsmith \& Eric A. Posner, Introduction, 31 J. LEGAL STUD. S1, S3 (2002) ("Rational choice is the general label for a variety of related methodological approaches to the study of goal-directed behavior under constraints of scarcity.").

84 Gary S. Becker, Crime and Punishment: An Economic Approach, 76 J. Pol. ECON. 169, 176 (1968) (" $[\mathrm{A}]$ person commits an offense if the expected utility to him exceeds the utility he could get by using his time and other resources at other activities.").

85 See, e.g., Elies van Sliedregt, The Curious Case of International Criminal Liability, 10 J. INT'L CRIM. JusT. 1171, 1182-83 (2012) (describing the evolution of the concept of fair labeling).

86 Robinson, supra note 1 , at 927.

$87 \mathrm{Id}$. at $927 \mathrm{n} .9$ (focusing on fair labeling as it pertains to "the difference between two forms of participation"). See also van Sliedregt, supra note 85, at 1183 (arguing for the importance of fair labeling with respect to "criminal participation" and the need to distinguish between principals and accessories). 
important to victims that their experience as so-called "bush wives" be understood differently from other harms that they had suffered. Thus, prosecutors sought convictions for forced marriage and crimes of sexual violence. Conviction for these crimes accurately signaled to all the full measure of the underlying wrongful conduct.

\section{c. Limitations}

There are several possible objections to the approach that I propose. In this Part I address four problems: the potential for subjectivity or abuse, the difficulty of addressing harms caused by systems of exploitation or caused to non-human entities, the possibility of further erosion of the legality principle and the potential for the erosion of the rights of defendants, and the politics of criminalization in the first place. None of these objections is insurmountable, but a fair analysis of my approach requires that I address them at least briefly.

\section{i. Subjectivity}

First, any approach that focuses on harms is vulnerable to manipulation or misuse. To see how this might be a problem, consider an example from a case from the former Yugoslavia. When the International Criminal Tribunal for the Former Yugoslavia was analyzing the meaning of "other inhuman acts," it described its approach as follows: "identify a set of basic rights appertaining to human beings, the infringement of which may amount, depending on the accompanying circumstances, to a crime against humanity." 88 It is possible that what prosecutors or others consider to be a basic right is itself contingent on their initial assumptions or other factors. This might well leave out disfavored groups; indeed, a version of this may be responsible for why harms that principally affect women and girls were taken less seriously than others for too long. Thus, it is important that I acknowledge that my approach might be subject to abuse.

88 Prosecutor v. Kupreškić, Case No. IT-96-16-T, Judgement, ๆ 566 (Int'1. Crim. Trib. for the Former Yugoslavia Jan. 14, 2000). To be sure, the court did not conclude that these were the sole considerations. 


\section{ii. Systemic Causes and Effects}

Second, this approach can omit the harms that are caused by systems of abuse, like those that come from systematic pillage. It may well be appropriate to treat the harms to a community as different from harms to individuals. This approach leaves out harms to non-human species. Degrading treatment to animals or the environment can be as harmful as anything done to humans, but it is important to acknowledge that this assertion is contested.

\section{iii. The Legality Principle}

A third possible objection centers on the requirements that international criminal law comply with the legality principle and that charges be sufficiently specific to comport with basic norms of due process and human rights. A harms-based approach could become, at its core, a victim-centered teleological interpretive rule. ${ }^{89}$ As argued most powerfully by Darryl Robinson, international criminal law risks losing its character as an authoritative system of criminal law when it deviates from due process norms. ${ }^{90}$ To the extent that courts continue to conclude that the object and purpose of all statutes or rules is to give victims as much protection as possible, and end impunity and ensure accountability by making conviction more likely, the regime is at odds with the strict due process application that should be part of any criminal law regime. ${ }^{91}$ Finally, the rigor with which courts apply the legality principle is already underwhelming.

One of the most compelling arguments in favor of the creation of the International Criminal Court and the development of international criminal law has been the potential to end impunity for those who perpetrate atrocities. ${ }^{92}$ Scholars have argued that the

89 See Vienna Convention on the Law of Treaties art. 31, May 23, 1969, 1155 U.N.T.S. 331 ("A treaty shall be interpreted in good faith in accordance with the ordinary meaning to be given to the terms of the treaty in their context and in the light of its object and purpose.").

90 Robinson, supra note 1.

91 Id. at 935-36.

92 For example, the Preamble to the Rome Statute of the International Criminal Court notes that one of the justifications for the creation of the International Criminal Court is that states were determined "to put an end to impunity for the 
need to end impunity is a compelling justification for the International Criminal Court's actions (or a valid basis for criticizing its inaction). ${ }^{93}$ It is certainly true that ending impunity is a laudable goal. But, the doctrinal consequences of this goal have contributed to some of the problems that a harms-based approach might help solve. ${ }^{94}$

In addition to the creation and justification of the International Criminal Court, the goal of ending impunity has been advanced to justify relaxing the legality principle and allowing for easier prosecution on novel theories. Although my approach does not directly implicate this issue, it is helpful to note that concerns about the legality principle may, at times, be less significant than they first appear. The legality principle exists, at least in part, to protect two core underlying values. The first is that defendants must have notice of the conduct for which they are to be held criminally liable. Convicting and punishing a defendant for conduct that was not defined as criminal at the time it was committed violates fundamental notions of due process. ${ }^{95}$ Second, and closely related, is that violations of due process run the risk of undermining the legitimacy of the proceedings. These considerations are surely important, but there are distinctive features of international criminal law that may make them less salient than they would be in the domestic context.

perpetrators" of serious international crimes. Rome Statute, supra note 39, pmbl. See also Christopher Keith Hall, The Powers and Role of the Prosecutor of the International Criminal Court in the Global Fight Against Impunity, 17 LEIDEN J. INT'L L. 121, 121-24 (2004) (arguing that one of the primary purposes of the International Criminal Court is to fight impunity, and that the structure and performance of the Office of the Prosecutor can determine whether the International Criminal Court can fulfill its mission).

93 See, e.g., Payam Akhavan, Beyond Impunity: Can International Criminal Justice Prevent Future Atrocities?, 95 AM. J. INT'L L. 7, 9-13 (2001) (describing the importance of ending impunity and the consequences of impunity on deterrence and prevention of serious international crimes). Other scholars have criticized the International Criminal Court for its failure to do more to end impunity. See generally Dawn L. Rothe \& Victoria E. Collins, The International Criminal Court: A Pipe Dream to End Impunity?, 13 INT'L CRIM. L. REV. 191 (2013) (arguing that structural problems with the International Criminal Court have prevented it from fulfilling its purpose of ending impunity).

94 See SáCouto, Sadat \& Sellers, supra note 13, at 241 (arguing that "highly restrictive jurisprudence" has made it difficult for prosecutors to win cases and thereby end impunity for grave crimes).

95 See, e.g., Van Schaack, supra note 4, at 121 (arguing that one of the primary justifications for the legality principle is "ensuring that individuals are capable of obtaining notice of prescribed conduct so they can rationally adjust their behavior to avoid sanction"). 
With respect to the notice issue, it is true that defendants might not have been on notice of the particular configuration of elements for which prosecutors seek a conviction. But international criminal law is only available and only prosecutes the most heinous crimes. International criminal law does not address minor crimes or technical violations of obscure rules. Instead, international criminal tribunals address only very serious atrocities which are recognized as wrongful in legal systems around the world. To be sure, the legality principle should be taken seriously, and it protects important values. But allowing international criminal law to accommodate novel harms is unlikely to result in the conviction of defendants who had no idea that their conduct was wrongful when it was committed. With respect to the legitimacy question, the legality principle works less directly. The legitimacy of an institution, and any individual prosecution, is largely a political issue. If the relevant stakeholders accept the legitimacy of the institution, even if it does allow for the prosecution of novel crimes, the legality principle's underlying considerations are satisfied.

A related issue with a harms-based approach is that it might be difficult for a defendant to argue in a principled way against the assertion that his or her conduct produced specific harms. If a victim testifies that the defendant's conduct harmed her in a particular way, there is no real evidence that a defendant could produce to refute that assertion. Similarly, it is difficult to imagine how a defendant could argue, for example, that the harms associated with forced marriage are not similar to those caused by established categories of sexual violence. What is more, doing so would involve denying the validity of the victim's subjective experience and alienating the court.

International criminal law is inevitably and unavoidably political. It is naïve to argue that it exists outside of politics. Decisions such as what harms are sufficiently important to justify a prosecution, and which are not, are themselves political choices. They take place within the constraints of the law, but choosing who counts and who does not is politics. To the extent that international criminal law exists, and is applied, to promote accountability, a harms-based approach is appropriate. Related to this is the perhaps obvious truth that interpretation of the law is not a scientific endeavor. Statutes and rules can be applied in many ways, and a victim-centered approach is the most appropriate choice. 


\section{iv. The Politics of Criminalization}

The issue of whether particular conduct warrants criminal punishment is a complex and important question, whether it arises in a single state or in a juridical institution created by many states. ${ }^{96}$ It is beyond the scope of this Article to provide a full theory of how and why certain acts are criminalized. But, before moving on, it is important to consider at least some of the competing theories of how conduct is criminalized to understand how new crimes might be created or justified.

Determining how a single state should decide whether to use the coercive authority of the state to punish people who engage in specified conduct goes to the core of state power. ${ }^{97}$ Most scholarly analyses of these issues focus on the legal-philosophical questions that underlie the legitimate justifications for the state to prosecute and punish wrongdoers. ${ }^{98}$ There has been comparatively little work on this issue in international criminal law, ${ }^{99}$ but the substantial work on the issue in domestic criminal law is instructive. Some scholars argue that the only appropriate function of the criminal law is the "the achievement of retributive justice."100 By this they mean that punishing wrongdoers as much as they deserve to be punished is the only legitimate justification for the state to use its coercive power in this way. On this account, the goal of defining crimes is, in part, to help determine which conduct justifies the imposition of punishment. Other scholars argue that deterrence is the appropriate justification for the use of criminal punishment. ${ }^{101}$ These scholars

96 See Alejandro Chehtman, A Theory of International Crimes: Conceptual and Normative Issues, in THE OXFORD HANDBOOK OF INTERNATIONAL CRIMINAL LAW (K.J.

Heller et al. eds., forthcoming 2020),

https://papers.ssrn.com/sol3/papers.cfm?abstract_id=3082869

[https:/ / perma.cc/G82S-F4LD].

97 See, e.g., JOHN StUART MiLL, ON LibERTy (Longmans, 2011) (1859).

98 See generally, Michael S. MoOre, Placing Blame: A Theory of the CRIMINAL LAW 84 (1997) (analyzing the "prima facie reasons given to justify the institution of punishment").

99 For a theoretical account of the arguments for and against desert-based theories of international criminal law, see Andrew K. Woods, Moral Judgments $\mathcal{E}$ International Crimes: The Disutility of Desert, 52 VA J. INT'L L. 633, 638 (2012) (arguing that an international criminal law response is not "retributive to its core", but is "justified by the view that desert serves the many policy goals of the" response).

100 See MoORE, supra note 98, at 78-79.

101 See generally, Paul H. Robinson \& John M. Darley, The Role of Deterrence in the Formulation of Criminal Law Rules: At Its Worst When Doing Its Best, 91 GEO. L.J. 949 (2003). 
maintain that punishment is justified for those who violate the law at least partly because of the effect this punishment will have on other people who may be considering whether to break the law. Finally, some scholars argue that a primary justification for prosecution and punishment is incapacitation. ${ }^{102}$ On this approach, the state is justified to use its coercive power to take wrongdoers out of society to prevent them from harming others. ${ }^{103}$

Debates about criminalization in international criminal law implicate many of these issues, but criminalization inevitably raises problems that are much messier than mere theoretical arguments. Part of the reason is that each of the theoretical justifications of punishments, at least as advanced by most scholars, amount to attempts to identify the sole or primary reason to punish. ${ }^{104}$ Even if such purity was possible in domestic legal systems, it is not conceivable in an international system. In international criminal law, the picture is much more complex. There are far more potential wrongdoers than international institutions could ever punish. It is unclear whether international institutions can have a deterrent effect. Perhaps more importantly, international legal institutions are created with so many purported objectives - not all of which may even be compatible with each other-that they must balance political considerations alongside theoretical and legal considerations. Even having acknowledged that it is unavoidable that criminalization in the international system will involve a wide range of considerations, it is nonetheless useful to consider how particular acts come to be defined as crimes.

Defining crimes in the international system has involved a backand-forth process implicating the traditional considerations of malum in se and malum prohibitum. 105 Some core international crimes first faced prosecution not because they were the subject of specific, well-known definitions but because the underlying conduct was considered so evil that not prosecuting it was viewed as wrongful. 106

102 For a discussion on the justification of incapacitation, see generally Paul $\mathrm{H}$. Robinson, Hybrid Principles for the Distribution of Criminal Sanctions, 82 Nw. U. L. REV. 19, 22 n.15 (1987-1988).

103 See, e.g., Kent Greenawalt, Commentary, Punishment, 74 J. CRIM. L. \& CRIMINOLOGY 343 (1983) (recognizing that preventing harm to others by removing offenders is a principal justification for criminal punishment).

104 See, e.g., Keenan, supra note 3, at 448-49.

105 See STAHN, supra note 42, at 19-22.

106 See generally David Luban, A Theory of Crimes Against Humanity, 29 YALE J. INT'L L. 85 (2004) (illustrating that crimes against humanity pose a universal threat to humankind, which shares an interest in minimizing these crimes). 
For example, prosecution of crimes against humanity became possible largely because scholars and advocates came to believe that some acts were so heinous that they required prosecution, even if the acts did not fit neatly into existing categories of crimes. ${ }^{107}$ This approach to defining wrongful conduct covered a number of crimes that are now well recognized. For example, pirates were considered the enemies of all mankind. 108 Because their acts were so evil, they could be prosecuted by any state that caught them. ${ }^{109}$

Other scholars argue that the classical conception of sovereignty means that crimes may be prosecuted only if states agree that they should be punished. ${ }^{110}$ On this approach, the inherent wrongfulness of an act is perhaps less important than whether the act has been subject to individual criminal prosecution in enough states or the subject of an international convention.

The reality of criminalization at the international level is an amalgam of these theories (with a measure of politics mixed in as well). Consider Raphael Lemkin's arguments in favor of the criminalization and prosecution of the crime of genocide. He argued that "[i]f the destruction of human groups is a problem of international concern, then such acts should be treated as crimes under the law of nations, like piracy." 111 For Lemkin, this meant that those alleged to have committed genocide should be prosecuted "irrespective of the nationality of the offender and of the place where the crime was committed." 112 Lemkin was making an argument about how the international legal system should address crimes the effects of which were considered similarly harmful. If genocide was as harmful as piracy, then it should be prosecuted as piracy was prosecuted. This argument was an attempt to bridge the

107 See Robert H. Jackson, Representative \& Chief of Counsel for the U.S., Opening Statement for the United States of America at the International Military Tribunal N.1 at The Palace of Justice, Nuremberg , Germany 1 (Nov. 21, 1945), https:/ / digitalcommons.law.uga.edu/cgi/viewcontent.cgi?article=1010\&context =imt [https://perma.cc/C9U5-DUBM] ("The wrongs which we seek to condemn and punish have been so calculated, so malignant and so devastating, that civilization cannot tolerate their being ignored because it cannot survive their being repeated.").

108 See STAHN, supra note 42, at 19.

109 Id.

110 See e.g., Robert Cryer, International Criminal Law vs State Sovereignty: Another Round?, 16 EUR. J. INT'L CRIM. L. 979, 985-87 (2005) (analyzing the connections between state consent, sovereignty, and the reach of international criminal law).

111 Lemkin, supra note 44, at 146.

112 Id. 
theoretical gap between those who sought prosecution for inherently evil acts, even if they had not yet been criminalized, and those who would restrict prosecution to those acts that were defined and accepted as crimes by a majority of states. This approach grounded any expansion of international law in some consideration of existing crimes. If its harms were not similar to existing crimes, then it would be much more difficult to justify prosecuting the new crime.

\section{EXTENSIONS AND COMPLICATIONS}

In this Part, I illustrate how a harms-based approach might be productively deployed to address harms that are not currently fully addressed in international criminal law. This Part is necessarily speculative. My objective is to show that this approach has the potential to affect real cases, not that it will be a winning argument in every case. First, I show how it could bolster attempts to use international criminal law to prosecute individuals for harms that affect entire communities, such as the pillaging of conflict minerals. Then, I argue that this approach could be used to address harms associated with climate change.

\section{a. Community-Based Harms}

There are several possible applications of a harms-based theory of criminalization. Before examining them in more detail, it is important to note that these applications show how a harms-based approach might inform both charging decisions and the definitions of crimes. When prosecutors are faced with the complex bundle of facts that can arise after an investigation into atrocities or a prolonged period of conflict, they have several important problems to solve. Two are particularly relevant here. The first is to identify the legal categories into which they can fit the wrongful conduct they have identified. This is a problem of identifying the appropriate crimes and sorting the wrongful conduct accordingly. Part of my argument is the catalog of available categories has been, and should further be, expanded based on a consideration of the harms caused by the wrongful conduct. This is, for example, how the crime of forced marriage came into existence. Another part of 
my argument is that prosecutors can, and should, use existing categories more creatively when they make charging decisions. This is an issue of prosecutorial discretion: when faced with a surplus of evidence of wrongdoing, and constrained by scarce resources and time, which crimes should be charged?

The examples I examine in this Part address both of these issues. I first consider the law of pillage, an increasingly common phenomenon in armed conflict. I argue that prosecutors should use their existing charging discretion differently to account for harms that are currently not covered in typical cases. ${ }^{113}$ There are harms to the community that are not addressed when prosecutors focus only on discrete episodes of pillage and fail to address the systematic pillage of natural resources. I next consider environmental harms and the potential to use international criminal law to address the harms associated with climate change. ${ }^{114}$ Here, I argue that there are harms to non-human species and to ecosystems that are not covered by existing categories.

In many modern conflicts, it is common for one or more of the combatant groups to exploit natural resources to enrich itself, pay for the war, or enrich its allies. 115 The prosecutorial strategy most commonly used is viewed as unsatisfactory by many scholars and advocates who have considered it. Part of the reason that the legal strategy is inadequate is that it does not adequately address all of the underlying harms caused by the exploitive behavior. 116

113 In an earlier Article I covered this issue in much more detail and I draw on that work here. See generally Keenan, supra note 76 (analyzing the law of pillage and arguing for a systemic theory of pillage to permit the prosecution of a broader range of harms).

114 In making these arguments, I rely on Patrick J. Keenan, International Criminal Law and Climate Change, 37 B.U. INT'L L.J. 89 (2019), in which I argued that international criminal law could, under appropriate and limited conditions, contribute to the fight against climate change.

115 See, e.g., Jean D'Aspremont, Towards an International Law of Brigandage: Interpretative Engineering for the Regulation of Natural Resources Exploitation, 3 AsIAN J. INT'L L. 1, 3-8 (2013) (noting that the humanitarian law prohibition on pillage has been the principal legal mechanism used to address resource exploitation and arguing that it has been inadequate to this point); Ruben Carranza, Plunder and Pain: Should Transitional Justice Engage with Corruption and Economic Crimes? 2 INT'L J. TRANSITIONAL JUST. 310, 329 (2008) (arguing that transitional justice mechanisms, including criminal prosecutions, should address economic exploitation during conflict to avoid creating an "impunity gap" that can arise when prosecutors ignore "large-scale corruption and economic crimes").

116 See, e.g., Larissa van den Herik \& Daniëlla Dam-De Jong, Revitalizing the Antique War Crime of Pillage: The Potential and Pitfalls of Using International Criminal 
Prosecutions using a harms-based strategy would approach the problem differently. Instead of focusing exclusively on discrete, small-scale episodes of pillage, they would address larger-scale systems of exploitation that cause the most harm to the most people.

The crime of pillage is the charge most often used by prosecutors to address this kind of exploitation. In modern international criminal law, the crime of pillage occurs when someone appropriates property during a conflict with the intent to deprive the owner of the property and to put the property to private or personal use. 117 There are, of course, other tools available to prosecutors seeking to hold individuals accountable for this exploitation, but the crime of pillage is most commonly used. ${ }^{118}$ This approach is consistent with modern international criminal law, but does not adequately address the underlying harms caused by much of the exploitation seen in modern conflicts. Prosecutors often adopt what I have called elsewhere the "episodic theory of pillage." 119 When they used the episodic approach to prosecuting pillage, prosecutors focused on discrete, often small-scale episodes of theft during armed conflict. ${ }^{120}$ Consider two examples.

In Prosecutor v. Brima from the Special Court for Sierra Leone, the defendants were convicted of the war crime of pillage. ${ }^{121}$ The

Law to Address Illegal Resource Exploitation During Armed Conflict, 15 CRIM. L.F. 237, 272-73 (2011) (arguing that the crime of pillage, as currently deployed by prosecutors, has limited utility as a way to address the harms of resource exploitation during armed conflict).

117 See Jean-Marie Henckaerts \& Louise Doswald-Beck, Customary INTERNATIONAL HUMANITARIAN LAW 185 (2005) (describing the prohibition on pillage as the prohibition of theft during wartime).

118 See van den Herik \& Dam-De Jong, supra note 116, at 272-73 (describing shortcomings of the current law of pillage).

119 See Keenan, supra note 76, at 534.

120 For a complete inventory of every case involving pillage, see JAMES G. Stewart, Corporate War Crimes: Prosecuting the Pillage of Natural RESOURCES 95-124 (2011). Stewart catalogues every decision on pillage from an international criminal tribunal and many from domestic courts that were based on incidents that occurred during a conflict.

121 See Prosecutor v. Brima, Case No. SCSL-04-16-T, Judgement, $\mid$ - 2113, 17, 21 (June 20, 2007). In the Special Court for Sierra Leone, only those defendants who bore the most responsibility for the violence in Sierra Leone were tried. See Sierra Leone Agreement, supra note 23, art. 1(1) (providing that the Special Court shall have the power "to prosecute persons who bear the greatest responsibility for serious violations of international humanitarian law and Sierra Leonean law"). This resulted in a total of four major cases, one against each of the three principal warring factions, plus one against former Liberian president Charles Taylor. 
convictions ${ }^{122}$ were based on the theft during armed conflict of "palm wine," 123 "televisions, radios and other goods,"124 and a "gold plated wrist watch." 125 In a separate case, the pillage counts alleged the theft of similar goods and more substantial goods such as a "baling machine and some . . f furniture,"126 and "bags of money."127 In Prosecutor $v$. Blaskic, ${ }^{128}$ from the International Criminal Tribunal for the Former Yugoslavia, the defendants were charged with stealing "civilian personal property and livestock."129 Cases like this are important because they recognize and address harms felt by individual victims and their survivors. But they also involve discrete objects or products that were not part of a larger system of exploitation, even if they were surely useful to those who stole them.

What is more, these discrete episodes of pillage are different from the large-scale exploitation of natural resources because there is not a clear connection between the appropriation and the conflict. There is little evidence that the theft of palm wine, radios, or televisions sustained the wars in West Africa in a substantial way. Instead, the acts of pillage supported the fighting, but did not appear to fuel it. For example, in Delalic and other cases from the former Yugoslavia, the stolen property was a form of supplement to the wages of individual fighters. ${ }^{130}$ It was not an important component of a broader scheme to pay for the war or the underlying motivation for the fighting. ${ }^{131}$ In Brima, from Sierra Leone, the picture is a bit

122 Because there were only four major cases, each case included wide-ranging factual allegations against multiple defendants. In Brima, the allegations underlying the pillage count spanned five separate geographic areas and occurred over approximately twenty months. See Prosecutor v. Brima, Case No. SCSL-04-16T, Judgement, I 1395 (June 20, 2007). The factual allegations noted above are representative of those in the case.

123 Id. ๆ 1413.

124 Id. $\uparrow 1426$.

125 Id.

126 Prosecutor v. Charles Taylor, SCSL-03-01-T, Judgement, ๆ 1894 (May 18, 2012).

$127 \quad$ Id. $\uparrow 1890$.

128 Prosecutor v. Blaskic, Case No. IT-95-14, Second Amended Indictment (Int'l Crim. Trib. for the Former Yugoslavia April 25, 1997).

129 Id. $\ 6.3$.

130 See, e.g., Prosecutor v. Delalic, Case No. IT-96-21-T, Judgment, ๆ 1151-1154 (Int'1 Crim. Trib. for the Former Yugoslavia Nov. 16, 1998) (finding that items stolen from prisoners were not of sufficient value to satisfy legal requirements).

131 See Prosecutor v. Blaskic, Case No. IT-95-14-T, Judgment, ๆ 1154 (Int'l Crim. Trib. for the Former Yugoslavia March 3, 2000) (describing items stolen by defendant). 
cloudier, but still supports the argument. There, the fighters engaged in theft as part of a plan to support themselves while they were fighting. Indeed, one episode the prosecutors focused on was part of a scheme called "Operation Pay Yourself" by those involved. ${ }^{132}$ In that scheme, commanders granted lower-level fighters permission to steal from civilians as a way to pay for their own survival. ${ }^{133}$ The thefts principally benefitted those who did the actual stealing, and did not provide the impetus for the armed conflict. 134

Contrast this with what I have called the systematic theory of pillage.135 This approach would retain the same basic elements of the crime, but give more weight to different harms, those that are unaddressed by current prosecutions. With a systematic theory of pillage, prosecutors could target broader harms, especially those harms to a community. Pursuant to a systematic theory of pillage, prosecutors would be required to prove that the defendant controlled the instrumentality or system by which the defendant appropriated the property. This could be done by showing that the combatants under the defendant's command controlled, for example, a mine (or other resources). The acts of appropriation might take place over a longer time period than the discrete episodes and might involve more participants.

Most important for my purposes is that the harms are different than those addressed with the episodic pillage cases. In typical, episodic pillage cases, the harms are those associated with theft cases. Victims are deprived of their property. They suffer the violation that comes from having their homes, farms, or businesses invaded by armed fighters seeking to steal from them. These are important harms that the law rightly addresses. The harms associated with the systemic pillage of natural resources are different and are not covered by other charges. The harms are many. Communities are permanently deprived of resources necessary to

132 See Prosecutor v. Brima, Case No. SCSL-04-16-T, Judgement, ๆ 1398 (June 20, 2007); see also James Rupert, Diamond Hunters Fuel Africa's Brutal Wars, WasH. POST, Oct. 16, 1999, at A1 (reporting on the effects of "Operation Pay Yourself" on the civilian population).

133 See Rupert, supra note 132.

134 For example, some of the vehicles commandeered and some of the money stolen from banks apparently went to commanders rather than those who actually stole the property. See Prosecutor v. Sesay, Case No. SCSL-04-15-T, Judgment, I 782-786 (Mar. 2, 2009).

135 See generally Keenan, supra note 76 (arguing that the systemic approach to the law of pillage could address more harms than the current approach). 
reach their economic potential or to fully develop. Community members are forced to work on behalf of a system that is impoverishing them, even if they are paid for their labor or undertake the work voluntarily. Indeed, their labor is used in a way that exacerbates long-term suffering and deprivation by prolonging the conflict and making it more lethal. Charging pillage under a systematic theory would address these harms.

Consider two examples to see how this might work. Former Liberian president Charles Taylor was convicted of a range of crimes by the Special Court for Sierra Leone for his role in the wars in West Africa in the 1990s. Indeed, Taylor was convicted of pillage-based on the actions of troops under his command - for "Operation Pay Yourself." 136 But he was not charged with or convicted of pillage or anything else for his role in systematically looting Sierra Leone's natural resources. ${ }^{137}$ There is substantial evidence that Taylor was involved in the systematic pillaging of many natural resources in Sierra Leone, including diamonds and timber, and that the proceeds from these activities fueled the war. ${ }^{138}$ The community-based harms caused by these acts were substantial and continued to affect the victimized communities for years. 139 But the charges pursued by prosecutors did not address these harms in any substantial way. ${ }^{140}$

The second example comes from the prosecution of Bosco Ntanganda in the International Criminal Court. Ntaganda was convicted in the International Criminal Court in July 2019 of a number of crimes relating to his role in the wars in Eastern Congo. ${ }^{141}$ Importantly, he was not charged or convicted for his role in the

136 Prosecutor v. Charles Taylor, SCSL-03-01-T, Judgment, ๆ $\uparrow$ 1878, 1963 (May 18, 2012); see also Rupert, supra note 132 (reporting on the effects of "Operation Pay Yourself" on the civilian population).

137 Id. ๆ 6994.

138 See generally Ruben De Koning, Greed or Grievance in West Africa's Forest Wars?, in EXTREME CONFLICT AND TROPICAL Forests 37 (Wil De Jong, Deanna Donovan \& Ken-Ichi Abe eds., 2007).

139 For an analysis of the substantial losses to the communities caused by illicit timber operations, see Rep. of the Panel of Experts on Liberia (2001), transmitted by Letter dated 26 October 2001 from the Chairman of the Security Council Comm. Established Pursuant to Resolution 1343 (2001), Paragraph 19, Concerning Liberia Addressed to the President of the Security Council, I $1321-49$, U.N. Doc. S/2001/1015 (Oct. 26, 2001).

140 See Prosecutor v. Taylor, Case No. SCSL-03-01-I, Amended Indictment (Mar. 16, 2006). Taylor was charged with several specific instances of pillaging, but not for the systematic exploitation of natural resources. Id. ๆ 9 28-31.

141 See Prosecutor v. Ntaganda, Case No. ICC-01/04-02/06, Judgment, at 53538 (July 8, 2019) (listing crimes for which Ntaganda had been convicted). 
exploitation of Congo's natural resources. ${ }^{142}$ Ntaganda is an ethnic Tutsi, born in Rwanda and raised in eastern Congo. ${ }^{143}$ He began his career in the Rwandan Patriotic Army 144 and particpated in displacing Mobutu Sese Seko and replacing him with Laurent Kabila. ${ }^{145}$ After that, Ntaganda was involved in fighting in eastern Congo, rising to become the chief of military operations in the Congolese region of Ituri for one of the main rebel groups there. ${ }^{146}$ There, Ntaganda was involved in the forcible recruitment of child soldiers, commanded troops that engaged in deadly campaigns of mass rape, murder, and other international crimes. ${ }^{147}$ Eventually he was charged in the International Criminal Court with the war crime of pillage, among many other crimes. But the charges against him did not include many of the most significant harms that flowed from his activities: the systematic pillaging of natural resources that helped fund the conflict. ${ }^{148}$ The harms to the community that came from having non-renewable wealth stolen were not addressed but could have been.

Before moving on, a short caveat is in order. I do not argue that a harms-based approach would inevitably lead to more prosecutions of the kind that I have identified. Instead, I argue that there is room within existing law for such an approach, and that doing so would be consistent with important principles of international law. The law has long struggled with the recognition that the human capacity to cause harm would always outstrip the predictive powers of scholars and advocates. It is increasingly difficult for the International Criminal Court to justify its track

142 See Prosecutor v. Ntaganda, Case No. ICC-01/04-02/06, Updated Document Containing the Charges (Nov. 14, 2014). Ntaganda was charged with pillaging for a number of discrete acts of theft by forces under his control. Id. I $\uparrow$ 67, 72, 77-78, 81, 84-85.

143 See Prosecutor v. Ntaganda, Case No. ICC-01/04-02/06, Judgment, ๆ 1 (July 8, 2019).

144 See DR Congo: Suspected War Criminal Wanted, Hum. RTs. Watch (Apr. 29, 2008), http://www.hrw.org/news/2008/04/29/dr-congo-suspected-warcriminal-wanted [https:/ / perma.cc/2Q8Z-F8TZ].

145 See Prosecutor v. Ntaganda, Case No. ICC-01/04-02/06, Judgment, ๆ (July 8, 2019) (describing Ntaganda's role in early wars in Congo).

146 Id. I 12-32 (describing Ntaganda's role in later conflict in Congo).

147 See The Enough Project, Fact Sheet: Who is Bosco Ntaganda: Lynchpin to Security or International War Criminal, ENOUGH (Apr. 2012), https://enoughproject.org/files/BoscoNtaganda.pdf [https://perma.cc/6VJEBS8L].

148 See Prosecutor v. Ntaganda, Case No. ICC-01/04-02/06, Judgment, at 53538 (July 8, 2019) (listing crimes for which Ntaganda had been convicted). 
record. Twenty years into its existence, the International Criminal Court has not had the effect its most ambitious proponents would have preferred. Indeed, the Office of the Prosecutor acknowledged that it had not fully realized its potential in its Strategic Plan, released in 2019.149 In it, the OTP set as goals the need to have a higher success rate in court and to accomplish this in significant part by the way it chooses and develops cases in their early stages. ${ }^{150}$ The law has room to evolve to account for more harms, done to more people, communities, and things, than it has so far fully recognized.

\section{b. Harms to Non-Human Species and the Environment}

A second potential application is in the area of environmental crimes. Scholars and advocates have long sought plausible ways to use criminal law, including international criminal law to address the harms that come from climate change. One prominent scholar has argued that causing harms to the environment should amount to an international crime because doing so is a breach of an erga omnes norm prohibiting actions that cause gross harm to the environment. ${ }^{151}$ Another advocate has gone so far as to propose a statute that would criminalize such conduct. 152 This proposal is explicitly based on the argument that the harms associated with deliberate environmental destruction are similar to the harms associated with other core international crimes, both in scale and in moral seriousness. ${ }^{153}$

\footnotetext{
149 See InT'L CRIM. CT., The Off. Of THe Prosecutor, Strategic Plan: 2019-2021 at 13-15 (July 17, 2019) (describing goal of increasing success rate in court).

150 Id. at 13-22.

151 See Mark Allan Gray, The International Crime of Ecocide, 26 CAL. W. INT'L L.J. 215, 270 (1996).

152 See Polly Higgins, Eradicating Ecocide: Laws AND Governance to Prevent the Destruction of Our Planet 61-63 (2d ed. 2015).

153 Id. There is, of course, much more scholarship on this issue. See, e.g., Berat, supra note 20, at 343-44; POlly Higgins, ECOCIDE DiRective art. 1.1, http:/ / eradicatingecocide.com/the-law/ecocide-directive/ [https://perma.cc/R5ZX-QA9Z]; Polly Higgins, Damien Short \& Nigel South, Protecting the Planet: A Proposal for a Law of Ecocide, 59 CRIME, L. \& SOC. CHANGE 251 (2013).
} 
These attempts have not born fruit, in part because of doctrinal problems that a harms-based approach could help to solve.154 A prosecutor attempting to pursue a case involving environmental crimes would likely face an objection that the charges violated the legality principle. This requires that the substantive activity be defined as unlawful and that those who engaged in the activity be subject to individual criminal prosecution. There is an increasing number of cases demonstrating that activity that causes climate harms is unlawful. 155 More difficult would be an attempt to demonstrate that the underlying behavior was subject to individual criminal prosecution. It is here that the harms-based approach, akin to that taken in Brima, would be most useful. Consider a proposed definition of such a crime, put forth by Lynn Berat:

[T] he intentional destruction, in whole or in part, of any portion of the global ecosystem, via killing members of a species; causing serious bodily or mental harm to members of the species; inflicting on the species conditions of life that bring about its physical destruction in whole or in part; and imposing measures that prevent births within the group or lead to birth defects. ${ }^{156}$

As in Brima, the underlying actions are already subject to individual criminal prosecution in many places. And, more importantly, a harms-based approach would make harms to nonhuman species and the environment cognizable.

154 The Office of the Prosecutor at the International Criminal Court recently released a policy paper on case selection that seems to recognize the importance of this issue, which may signal a willingness to address it in cases. See Alessandra Mistura, Is There Space for Environmental Crimes Under International Criminal Law? The Impact of the Office of the Prosecutor Policy Paper on Case Selection and Prioritization on the Current Legal Framework, 43 COLUM. J. ENV'T. L. 181 (2018); INT'L CRIM. CT., THE OfF. OF the Prosecutor, Policy Paper on Case Selection and Prioritisation (Sept. 15, 2016), https://www.icc-cpi.int/itemsDocuments/20160915_OTP-Policy_CaseSelection_Eng.pdf [https://perma.cc/VK2C-FQ4P].

155 See generally Hari M. Osofsky, The Continuing Importance of Climate Change Litigation, 1 CLIMATE L. 3 (2010) (analyzing the various ways that climate change litigation in domestic courts is affecting transnational attempts to address climate change); Hari M Osofsky \& Jacqueline Peel, The Role of Litigation in Multilevel Climate Change Governance: Possibilities for a Lower Carbon Future?, 30 ENV'T \& PLAN. L.J. 303 (2013) (comparing the ways that Australia and the U.S. have addressed climate change in litigation and regulatory processes); Brian J. Preston, The Influence of Climate Change Litigation on Governments and the Private Sector, 2 ClimATE L. 485 (2011) (surveying the influence of domestic climate change litigation on decision makers from the legislative and executive branches).

156 See Berat, supra note 20, at 343. 


\section{CONCLUSION}

International criminal tribunals have long struggled to fit novel harms into existing legal categories. Courts must balance the rights of defendants to know in advance the charges they might face with the reality that people have a seemingly endless ability to commit novel atrocities in armed conflict. Without a legislature or other body to define crimes, international criminal tribunals must strike this balance while also attempting to do justice for victims and perpetrators. The approach I advocate has the potential to effectively accomplish these goals. 